\title{
DIMENSI DAN STRUKTUR IPS
}

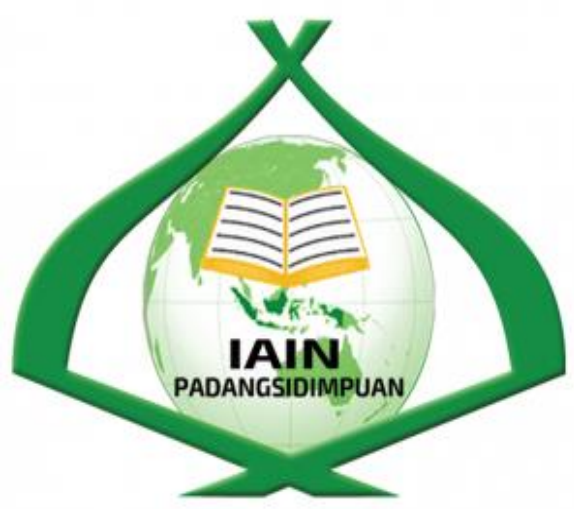

Disusun Untuk Memenuhi tugas Kelompok Oleh :

Kelompok 4 :

$\begin{array}{ll}\text { Rio Alvin Ritonga } & 1820500106 \\ \text { Adelina Lubis } & 1820500033 \\ \text { Ika Nur Aini Nasution } & 1820500151 \\ \text { Hasanah Dwi Fanshe Lubis } & 1820500089\end{array}$

Dosen Pembimbing :

Nashran Azizan, M. Pd.

FAKULTAS TARBIYAH DAN ILMU KEGURUAN PENDIDIKAN GURU MADRASAH IBTIDAIYAH INSTITUT AGAMA ISLAM NEGERI (IAIN) PADANGSIDIMPUAN T.A. $2019 / 2020$ 


\section{KATA PENGANTAR}

Assalamu'alaikum wr.wb.

Puji dan syukur kami ucapkan kepada allah SWT, yang telah memberi kami jalan kemudahan dan kekuatan dalam segala urusan yang kami hadapi, sehingga kami dapat menyelesaikan"makalah" kami yang berjudul " Dimensi dan Struktur IPS". Salawat serta salam tercurahkan kepada pemimpin ummat Islam yang memiliki ahklaqul qarimah yang dapat dijadikan suri tauladan yang baik semoga dengan berbanyak salawat kita termasuk ummat yang mendapatkan syafaat di hari akhir nanti amin.

Makalah ini di tujukan untuk memenuhi tugas mata kuliah“ Kosep Dasar I PS” dan juga dapat menambah wawasan pengetahuan kami bagi pemakalah, maupun wawasan teman-teman sekalian. Dan tak lupa pula kami ucapkan terima kasih banyak terhadap Dosen kami Ibu Nashran Azizan, M.Pd. yang telah bersedia membimbing kami dalam segenap waktu dan tempat. Kemudian, tak lupa pula atas bantuan teman-teman yang turut membantu kelancaran dalam penyusunan makalah ini. Jika terdapat kesalahan dalam penulisan ataupun adanya perbedaan pendapat dengan para pembaca, sekiranya dapat di maklumi dan dimohonkan kritik dan saran guna untuk membangun demi kesempurnaan tulisan ini. Sekian dan terima kasih.

Wassalamu'alaikum wr. wb.

Padangsidimpuan, 7 September 2019

Penyusun

Kelompok IV 


\section{Daftar Isi}

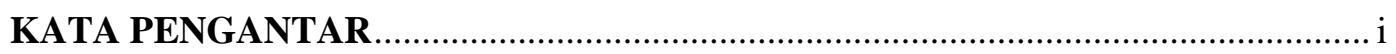

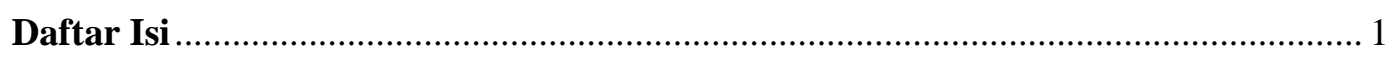

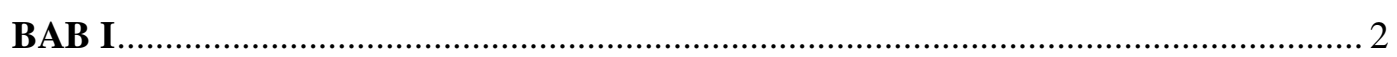

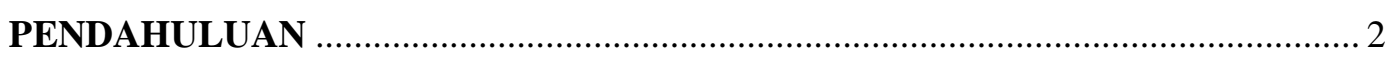

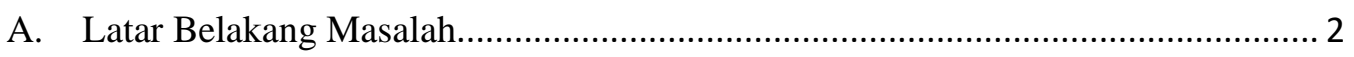

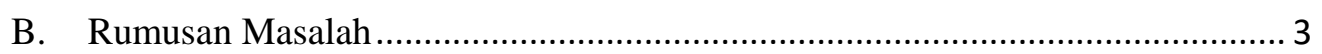

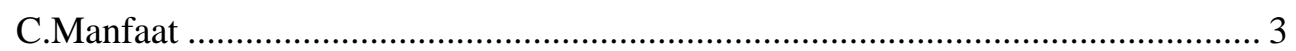

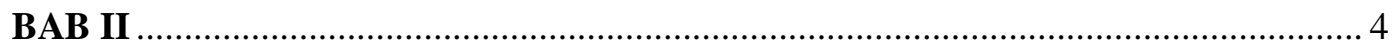

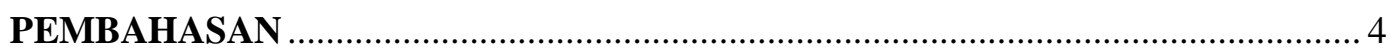

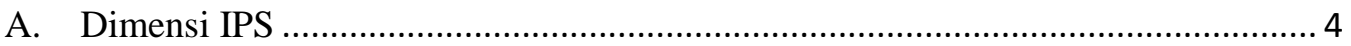

1. Dimensi Pengetahuan (knowledge) …………............................................. 4

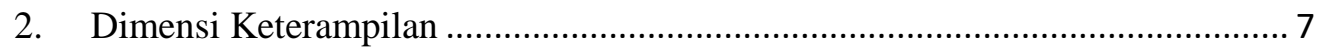

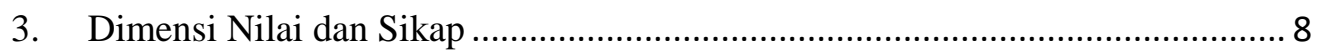

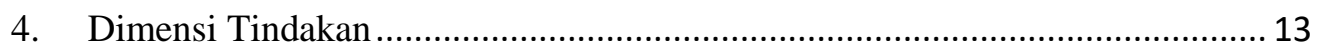

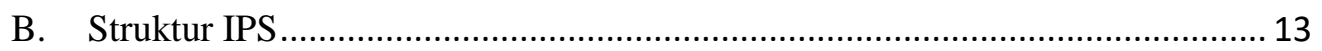

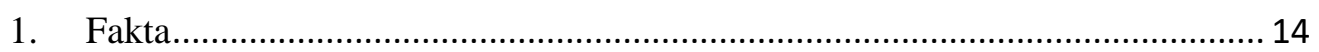

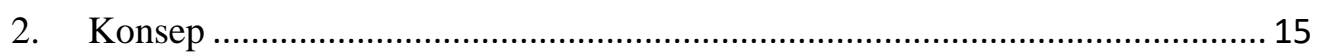

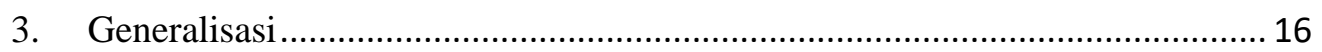

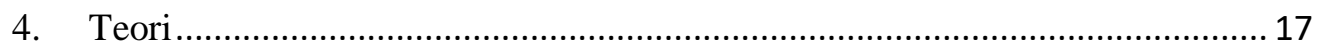

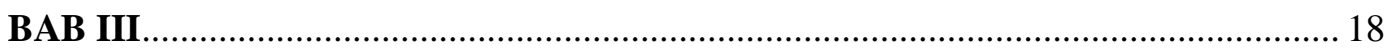

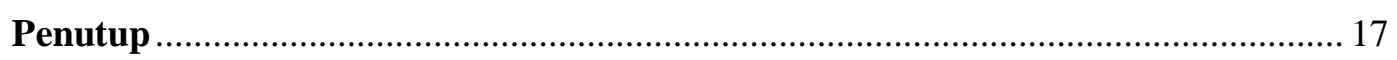

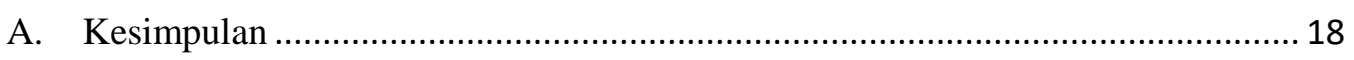

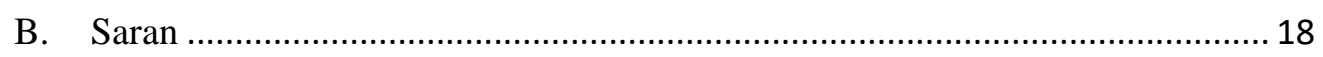

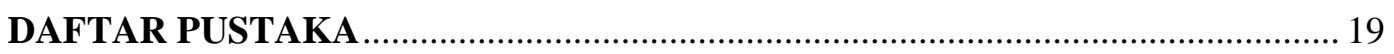




\section{BAB I}

\section{PENDAHULUAN}

\section{A. Latar Belakang Masalah}

Struktur adalah suatu tatanan yang membentuk suatu kelompok dalam masyarakat. Struktur mempunyai 3 ciri yakni berubah dan berkembang, ada di dalam masyarakat, dan berhubungan erat dengan masyarakat. Menurut prof. Benny H. Hoed bahwa pengertian struktur adalah bangun( teoretis) yang terdiri dari unsur-unsur yang berhubungan satu sama lain dalam satu kesatuan. Sedangkan menurut Wikipedia bahwa yang di maksud dengan struktur adalah sebuah gambaran yang mendasar dan kadang tidak berwujud, yang mencakup pengenalan, observasi, sifat dasar, dan stabilitas dari pola-pola dan hubungan antar banyak satuan terkecil di dalamnya. Jadi sruktur sosial adalah tatanan atau susunan sosial yang membentuk kelompok-kelompok sosial dalam masyarakat. Dalam hal ini struktur sosial susunannya dapat berupa horizontal maupun vertikal contoh struktur sosial horizontal adalah kelompok pria dan wanita, kelompok orang beragama islam, Kristen, katholik, hindu, budha, dan konghucu.Sedangkan vertikal adalah kelompok orang kaya, dan kelompok orang miskin, hal ini ini jelas menunjukkan kedudukan yang berbeda dalam masyarakat.

IPS adalah Ilmu Pengetahuan Sosial atau disingkat (IPS). Menurut Rosdijati, IPS merupakan salah satu mata pelajaran yang diberikan ditingkat SD/MI/SDLB, IPS mengkaji seperangkat peristiwa, fakta, konsep, generalisasi yang berkaitan dengan isu sosial. Jacob Bronowski, menjelaskan bahwa ilmu adalah aktivitas menyusun fakta-fakta yang di ketahui dalam kelompokkelompok di bawah konsep-konsep umum, dan konsep-konsep itu dinilai berdasarkan pernyataan dari tindakan-tindakan yang kita dasarkan padanya. Suatu struktur ilmu pengetahuan termasuk ilmu sosial tersusun dalam tiga tingkatan dari yang paling sempit ke yang luas, yaitu (1) fakta, (2) konsep, (3) generalisasi (4) teori dalam "Konsep Dasar IPS". Dengan demikian, dapat dikatakan bahwa batang tubuh ilmu strukturnya, mencakup fakta, konsep, 
generalisasi, dan teori. Maka dari itu untuk menjelaskan lebih lanjut mengenai struktur IPS, kami akan menyusun sebuah makalah yang berjudul “ Dimensi dan Struktur IPS", yang kami kumpulkan dari berbagai referensi yang ada dan kami padukan dengan perkataan para ahli terhadap struktur IPS.

\section{B. Rumusan Masalah}

1. Apa yang dimaksud dengan dimensi IPS ?

2. Apa yang dimaksud dengan Struktur IPS ?

\section{Manfaat}

1. Kita dapat mengetahui apa itu dimensi IPS ?

2. Kita dapat memahami Struktur IPS ? 


\section{BAB II \\ PEMBAHASAN}

\section{A. Dimensi IPS}

Dimensi dalam Pembelajaran IPS diajarkan secara terpadu dari 4 kajian, yaitu geografi, ekonomi, sejarah dan sosiologi melalui pendekatan tema. Pembelajaran ini berbasis pada kontekstual dengan mengamati dan belajar dari pengalaman sekelilingnya. Karakteristik IPS ini mampu menjadikan perkembangan psikologis peserta didik pada usia tersebut yang selalu ingin tau, berpikir kritis dan senang bereksplorasi.

Menurut Sapriya, program pendidikan IPS yang komperhensif adalah program yang mencakup empat dimensi, yaitu : dimensi pengetahuan (knowledge), dimensi keterampilan (skill), dimensi nilai dan sikap (values and attitudes), dimensi tindakan (action). Walaupun keempat dimensi ini memiliki karakteristik yang berbeda, namun dalam proses pembelajaran keempat dimensi ini saling melengkapi. Untuk kepentingan analisis akademik, keempat dimensi ini dibedakan agar guru dapat merancang pembelajaran IPS secara sistematis dan untuk meyakinkan bahwa semua kawasan sudah terliput.

\section{Dimensi Pengetahuan (knowledge)}

Setiap orang memiliki wawasan tentang pengetahuan sosial yang berdedabeda. Ada yang berpendapat bahwa pengetahuan sosial meliputi persitiwa yang terjadi di lingkungan masyarakat tertentu. Ada pula yang mengemukakan bahwa pengetahuan sosial mencakup keyakinan-keyakinan dan pengalaman belajar siswa. Pengetahuan mencakup 4 hal diantaranya pengetahuan faktual, pengetahuan konseptual, pengetahuan prosedural, dan pengetahuan metakognitif yang dipahami oleh peserta didik. 


\section{a. Pengetahuan Faktual}

Pengetahuan faktual meliputi elemen-elemen dasar yang digunakan oleh para ahli dalam mengkomunikasikan disiplin akademik, pemahaman, dan penyusunan dimensi pengetahuan secara sistematis. Elemen-elemen ini biasanya digunakan oleh orang-orang yang bekerja pada disiplin ilmu tertentu yang membutuhkan perubahan dari satu aplikasi ke aplikasi lain. Pengetahuan faktual berisi elemen-elemen dasar yang harus siswa ketahui ketika mereka harus mencapai atau menyelesaikan suatu masalah. Elemen-elemen ini biasanya dalam bentuk simbol-simbol yang digabungkan dalam beberapa referensi nyata atau 'rangkaian simbol' yang membawa informasi penting.

\section{b. Pengetahuan Konseptual}

Pengetahuan konseptual meliputi pengetahuan kategori dan klasifikasi serta hubungannya dengan dan diantara mereke-lebih rumit, dalam bentuk pengetahuan yang tersusun. Seperti, skema, model mental, atau teori implisit atau eksplisit dalam model psikologi kognitif yang berbeda. Semua itu dipersembahkan dalam pengetahuan individual mengenai bagaimana materi khusus di susun dan distrukturisasikan, bagaimana bagian-bagian yang berbeda atau informasi yang sedikit itu saling berhubungan dalam arti yang lebih sistematik, dan bagaimana bagian-bagian ini saling berfungsi.

\section{c. Pengetahuan Prosedural}

Pengetahuan prosedural meliputi pengetahuan tentang keterampilan khusus, tahapan sistematis mengenai sistem program (meliputi; input, proses, dan output). Prosedur berarti tahap demi tahap suatu proses untuk mencapai hasil yang diharapkan. Penguasaan pengetahuan prosedural berarti penguasaan proses, misalnya, siswa dapat melaksanakan penelitian melalui proses yang bertahap, yaitu (1) merumuskan pertanyaan (2) merumuskan latar belakang pemikiran (3) merumuskan hipotensi (4) menguji kebenaran hipotesis melalui eksperimen (5) analisis hasil atau menyimpulkan bahwa hipotesis benar atau salah (6) merumuskan hasil penelitian. 
Penguasaan prosedur bisa juga dalam proses berpikir yang dapat diwujudkan dalam proses berpersepsi, introspeksi, mengingat, berkreasi, berimajinasi, mengembangkan ide, atau berargumentasi. Di sini terdapat penguasaan untuk merumuskan atau mengikuti tahap kegiatan sesuai dengan proses yang seharusnya.

\section{d. Pengetahuan Metakognitif}

Metakognitif menurut Livingstone (1997) adalah "berpikir tentang berpikir”. Menurut Flavell sebagaimana dikutip Livingstone menyatakan bahwa metakognisi terdiri atas dua unsur yaitu pengetahuan dan pengalaman atau regulasi. Metakognitif merujuk pada proses mengusai ilmu pengetahuan dan proses berpikir. Dalam hal ini siswa dapat menggunakan ilmu pengetahuan yang telah dikuasinya untuk membangun pengetahuan baru. Metakognitif bisa juga dimaknai memiliki pemahaman mengenai belajar tentang cara belajar.

Flavell sendiri membagi metakognitif ke dalam tiga kategori, yaitu ilmu pengetahuan tentang variabel orang, variabel pekerjaan, dan variabel strategi. Memahami tipe belajar diri sendiri termasuk variabel orangnya. Variabel pekerjaan mencakup aktivitas belajar dan langkah kegiatan berpikir berpikir pada kegaitan belajar. Belajar menjadi proses beraktivitas dan berkarya. Variabel strategi menyangkut cara yang siswa gunakan untuk mewujudkan tujuan belajar.

Meningkatkan pengetahuan metakognitif akan terlihat pada strategi guru memfasilitasi siswa mengembangkan daya belajarnya tidak hanya mengembangkan sikap, keterampilan dan pengetahuannya namun siswa terampil belajar, mengembangkan kemandirian siswa dalam menerapkan berbagai cara sehingga dapat mengembangkan pengetahuan bermodalkan pengetahuan yang dipelajarinya. 
Jadi metakognitif memiliki kesamaan makna dengan berpikir tentang cara berpikir, belajar tentang belajar atau belajar tentang bagaimana cara belajar. Pengujian terhadap kemampuan ini bisa dilakukan dengan cara menantang siswa menunjukkan kompetensinya dalam bentuk menggunakan pengetahuan yang telah dipelajarinya untuk mengembangkan inisiatif belajar secara mandiri sehingga dapat mengembangkan pengetahuan barunya. Tugas mandiri untuk mengembangkan daya inisiatif sendiri, mengembangkan ide-ide kreatif, mendisain model baru, inisiatif baru, atau mengembangkan karya inoatif merupakan cara yang sesuai untuk menghimpun informasi tentang kemampuan belajar dengan mendayagunakan ilmu yang dimilikinya.

\section{Dimensi Keterampilan}

Pendidikan IPS sangat memerhatikan dimensi keterampilan disamping pemahaman dalam dimensi pengetahuan. Kecakapan mengolah dan menerapkan informasi merupakan keterampilan yang sangat penting untuk mempersiapkan siswa menjadi warga negara yang mampu berpartisipasi secara cerdas dalam masyarakat demokrastis. Oleh karena itu, berikut diuraikan sejumlah keterampilan yang diperlukan sehingga menjadi unsur dalam dimensi IPS dalam proses pembelajaran.

\section{a. Keterampilan Meneliti}

Keterampilan yang diperlukan untuk mengumpulkan dan mengolah data.

1) Mengidentifikasi dan mengungkapkan masalah atau isu

2) Mengumpulkan dan mengolah data

3) Menafsirkan data

4) Menganalisis data

5) Menilai bukti-bukti yang ditemukan

6) Menyimpulkan

7) Menerapkan hasil temuan dalam konteks yang berbeda

8) Membuat pertimbangan nilai 


\section{b. Keterampilan Berpikir}

Beberapa keterampilan berpikir yang perlu dikembangkan guru di kelas untuk peserta didik meliputi :

1) Mengkaji dan menilai data secara kritis

2) Merencanakan

3) Merumuskan faktor sebab dan akibat

4) Memprediksi hasil dari sesuatu kegiatan atau peristiwa

5) Menyarankan apa yang akan ditimbukan dari suatu peristiwa atau perbuatan

6) Curah pendapat

7) Berspekulasi tentang masa depan

8) Menyarankan berbagai solusi alternatif

9) Mengajukan pendapat dari perspektif yang berbeda

\section{c. Keterampilan Partisipasi Sosial}

Beberapa keterampilan partisipasi sosial yang perlu diajarkan oleh guru meliputi :

1) Mengidentifikasi akibat perbuatan dan pengaruh ucapan terhadap orang lain

2) Menunjukkan rasa hormat dan perhatian kepada orang lain

3) Berbagi tugas dan pekerjaan dengan orang lain

4) Berbuat efektif sebagai anggota kelompok

5) Mengambil berbagai peran kelompok

6) Menerima kritik dan saran

7) Menyesuaikan kemampuan dengan tugas yang harus diselesaikan 


\section{d. Keterampilan Berkomunikasi}

Pembelajaran adalah cara mendewasakan seseorang. Salah satu ciri seseorang yang sudah dewasa adalah dapat berkomunikasi dengan orang lain dengan baik. Oleh karena itu, pengembangan keterampilan berkomunikasi merupakan aspek yang penting dari pendekatan pembelajaran IPS khususnya dalam inkuiri sosial. Setiap peserta didik perlu diberi kesempatan untuk mengungkapkan idenya dalam bentuk lain seperti film, drama, seni, pertunjukan, foto, bahkan dalam bentuk peta. Para peserta didik seharusnya dimotivasi agar menjadi pembica dan pendengar yang baik. Semua keterampilan dalam pembelajaran IPS ini sangat diperlukan danakan memberikan kontribusi dalam proses inkuiri sebagai pendekatan utama dalam pembelajaran IPS.

\section{Dimensi Nilai dan Sikap}

Pada hakikatnya nilai merupakan sesuatu yang berharga. Nilai yang dimaksud disini ialah seperangkat keyakinan atau prinsip perilaku yang telah mempribadi dalam diri seseorang atau sekelompok masyarakat tertentu yang terungkap ketika berfikir atau bertindak. Nilai biasanya dipelajari sebagai hasil dari pergaulan atau komunikasi antar individu dalam kelompok seperti keluarga, himpunan keagamaan, kelompok masyarakat atau persatuan dari orang-orang yang memiliki tujuan yang sama. Agar ada kejelasan dalam mengkaji nilai dimasyarakat, maka nilai dapat dibedakan atas nilai substantif dan nilai prosedural. 


\section{a. Nilai Substantif}

Nilai substantif adalah keyakinan yang telah dipegang oleh seseorang dan umumnya hasil belajar, bukan sekadar menanamkan atau menyampaikan informasi semata. Setiap orang memiliki keyakinan atau pendapat yang berbeda-beda susuai dnegan keyakinannya tentang sesuatu hal. Misalnya setiap anggota keluarga akan berbeda pendangannya mengenai suatu hal, walaupun berasal dari satu keluarga yang sama namun tetap akan berbeda. Maka dalam hal ini suatu nilai dapat tergantung dari latar belakang orang tersebut, pendidikannya, kondisi ekonominya dan pengaruh lain yang dapat mempengaruhi makna nilai dari satu orang dengan orang yang lainnya. Dengan demikian keduudkan nilai bagi kelompok masyarakat dan individu merupakan komponen yang penting bagi pembelajaran IPS.

Dalam mempelajari nilai substantif peserta didik perlu memahami proses-proses, lembaga-lembaga, dan aturan-aturan untuk mmecahkan konflik dalam masyarakat yang demokratis. Dengan kata lain peserta didik mengetahui bahwa ada keberagaman nilai dalam masyarakat dan mereka perlu mengetahui isi nilai dan implikasi dari nilai-nilai tersebut dengan belajar nilai substantif, peserta didik dapat menjadi etrampil dalam mengenal dan menganalisis kedudukan nilai dari aneka ragam kelompok masyarakat.

Manfaat lain dari belajar nilai substantif adalah peserta didik akan menyatakan bahwa dirinya memiliki nilai tertentu. Dengan kata lain setiap peserta didik membawa nilai tersendiri dalam dirinya masing-masing yang tergantung pada beberapa faktor penyebab nilai itu melekat pada dirinya seperti latar keluarga, agama atau budaya. Selain itu guru juga perlu mneyadari bahwa nilai yang peserta didik anut tidak semuanya berlaku secara universal. Misalnya umat muslim diharuskan menunaikan ibadah puasa sebagai wujud dari nilai religius, maka guru harus memberi pengertian bahwa tidak semua peserta didik di kelas itu menunaikan 
Ibadan puasa jika memang berasal dari latar agama yang berbeda agar nantinya tidak terjadi konflik dalam kelas.

Oleh karena itu program pembelajaran IPS hendaknya memberikan kesempatan kepada peserta didik untuk mengungkapkan, merefleksikan, dan mengartikulasikan nilai-nilai yang dianutnya. Proses ini tergantung pada nilai-nilai prosedural di kelas. Peserta didik hendaknya didorong untuk bersiap diri membenarkan posisinya, mendengarkan kritikan yang ditujukan terhadap dirinya dan atau mengubah keputusannya jika ada pertimbangan lain, karena pada hakikatnya nilai adalah sesuatu yang berharga yang mengandung kebaikan maka diperlukan banyak pertimbangan untuk memastikan apakah hal tersebut memiliki nilai atau tidak.

\section{b. Nilai Prosedural}

Peran guru dalam memberikan pembelajaran dikelas sangatlah penting sesuai dengan langkah-langkah pembelajaran di kelas, maka nilai-nilai prosedural yang perlu dilatih atau dibelajarkan antara lain nilai kemerdekaan, toleransi, kejujuran, menghormati kebenaran, dan menghargai pendapat orang lain. Nilai-nilai ini merupakan kunci nilai yang dapat menyokong terciptanya masyarakat yang demokratis, seperti toleran terhadap pendapat yang berbeda, menghormati pribadi orang lain dan menghargai bukti yang sama serta bekerja sama. Apabila kelas IPS dimaksudkan untuk mengembangkan partisipasi peserta didik secara efektif dan diharapkan semakin memahami kondisi masyarakat Indonesia yang beraneka ragam, maka peserta didik perlu mengenal dan berlatih menerapkan nilai-nilai tersebut. Maka hendaknya penerapan nilai-nilai tersebut mulai dipraktikan ketika pembelajaran dikelas agar dapat dilatih sehingga kelak ketika terjun ke masyarakat peserta didik dapat mengimplementasikan nilai-nilai yang didapatkan dan menjadi warga negara yang bermartabat dan menghormati pribadi yang lain. 
Selain itu nilai dapat dibagi dalam dua kelompok, yaitu nilai nurani dan nilai 0 nilai memberi. Nilai nurani adalah nilai yang ada didalam diri manusia kemudaian berkembang menjadi perlaku serta cara kita memperlakukan orang lain yang termasuk niali-nilai nurani adalah kejujuran, keberanian, cinta damai, keandalan diri, potensi, tahu batas, kemurnian dan kesesuaian. Sedangkan nilai-nilai memberi adalah nilai yang perlu dipraktikkan atau diberikan yang kemudian akan diterima sebanyak yang dberikan. Yang termasuk pada kelompok nilai-nilai memberi adalah setia, dapat dipercaya, hormat, cinta, kasih sayang, peka, tidak egois, baik hati, ramah, adil, dan murah hati.

Dalam memberikan definisi tentang sikap, diantara para ahli banyak terjadi perdebatan. Terjadi hal ini karena sudut pandang yang berbeda tentang sikap itu sendiri. Studi mengenai sikap merupakan studi yang penting dalam bidang psikologi sosial. Konsep tentang sikap sendiri telah melahirkan berbagai macam pengertian diantara para ahli psikologi. Sikap pada awalnya diartikal sebagai suatu syarat untuk munculnya suatu tindakan konsep itu kemudian syarat untuk munculnya suatu tindakan konsep itu kemudian berkembang semakin luas dan digunakan untuk menggambarkan adanya suatu niat yang khusus dan umum berkaitan dengan kontrol terhadap respon pada keadaan tertentu. Berkowitz mengemukakan bahwa sikap seseorang terhadap suatu objek adalah perasaan mendukung atau memihak (favorable) maupun perasaan tidak mendukung atau tidak memihak (unfavorable) pada objek tersebut ${ }^{1}$. Nilai bersifat lebih mendasar dan stabil sebagai bagian dari cirri kepribadian, sikap bersifat evaluative dan berakar pada nilai yang dianut dan terbentuk dalam kaitannya dengan suatu objek.

\footnotetext{
${ }^{1}$ Azwar, S. Penyusun Skala Psikologi ( Yogyakarta : Pustaka Pelajar, 2012), hlm. 5
} 


\section{Dimensi Tindakan}

Dimensi tindakan sosial dapat diajarkan pada semua jenjang dan semua tingkatan kelas kurikulum IPS. Dimensi tindakan sosial untuk pembelajaran IPS meliputi 3 model aktivitas sebagai berikut :

a. Percontohan kegiatan dalam memecahkan masalah dikelas seperti cara berorganisasi dan bekerja sama. Misalnya, siswa usia 5 tahun memberikan pendapat kepada gurunya tentang tempat-tempat piknik apa saja sebagai alternatif dan mana yang akan dipilih.

b. Berkomunikasi dengan anggota masyarakat dapat diciptakan, misalnya dengan kelompok masyarakat pecinta lingkungan, masyarakat perajin, pedagang, dan melakukan survey, pengamatan, serta wawancara dengan pedagang di pasar tradisional.

c. Pengambilan keputusan dapat menjadi bagian kegiatan kelas, khususnya pada saat siswa diajak untuk melakukan inkuiri

\section{B. Struktur IPS}

Struktur IPS terdiri dari fakta, konsep, generalisasi, dan teori. Pemanfaatan fakta, konsep, generalisasi, dan teori dalam pengajaran IPS bukanlah suatu hal yang baru. Namun dalam proses belajar mengajar sering kali penggunaan istilah ini kurang tepat bahkan para peserta didik sering bingung apa yang dimaksud dengan fakta, konsep, generalisasi, dan teori tersebut. Hal ini disebabkan pengetahuan tentang fakta, konsep, generalisasi, dan teori tersebut bersifat abstrak.

Jacob Bronowski menjelaskan bahwa ilmu adalah aktivitas menyusun fakta-fakta yang diketahui dalam kelompok-kelompok dibawah konsep-konsep umum, dan konsep-konsep itu dinilai berdasarkan pernyataan dari tindakantindakan yang kita dasarkan padanya. 


\section{Fakta}

Fakta dalam bahasa latinnya disebut "factus" merupakan segala sesuatu yang tertangkap oleh indra manusia atau data keadaan nyata yang terbukti dan telah menjadi suatu kenyataan. ${ }^{2}$ Fakta ialah suatu objek, peristiwa, atau kejadian yang pernah terjadi pada saat ini, atau pernah ada pada masa lalu. Fakta dihasilkan dari data yang diperoleh di lapangan atau tempat penelitian dengan menggunakan penglihatan dan pendengaran, kemudian data diolah dengan prosedur tertentu, sehingga dihasilkanlah fakta ${ }^{3}$. Fakta sering kali diyakini oleh orang banyak (umum) sebagai hal sebenarnya, baik karena mereka mengalami kenyataan-kenyataan dari dekat maupun karena mereka dianggap telah melaporkan pengalaman orang lain yang sesungguhnya. Dalam istilah keilmuan fakta adalah suatu hasil pengamatan yang objektif dan dapat dilakukan verifikasi oleh siapa pun.Berkenaan dengan itu, untuk mendefinisikan fakta tidaklah semudah yang sering diucapkan. Terdapat berbagai pendapat dan tafsiran tentang fakta. Namun demikian, terdapat sejumlah ciri yang dapat menyatakan bahwa itu adalah fakta, yaitu :

1) Abstraksi dari kenyataan yang diamati.

2) Sifatnya khusus atau terbatas, jadi tidak bersifat general atau umum yang tidak terbatas (tidak ada duanya).

3) Erat hubungannya dengan jawaban atas apa, siapa, kapan, dimana, dan juga dapat berupa benda-benda yang benar-benar ada atau peristiwa apa yang pernah terjadi dimasa lalu.

4) Dapat diuji kebenarannya secara empiris.

5) Yang digunakan untuk mengembangkan konsep.

Contoh : dari fakta yang saling berkaitan untuk membentuk konsep sebagai berikut : Indonesia selamah tiga setengah abad dijajah oleh bangsa belanda. Sejak tahun 1908 bangsa Indonesia mulai berjuang untuk melawan penjajahan

\footnotetext{
${ }^{2}$ Idad Suhada, Konsep Dasar IPS (Bandung : CV Insan Mandiri, 2012), hlm. 12.

${ }^{3}$ Muhammad Kaulana Karima,Ilmu Pengetahuan Sosial (Medan :Perdana Publishing 2019), hlm. 148.
} 
yang dikenal dengan hari kebangkitan nasional. Dengan melalui perjalanan yang panjang dengan pengorbanan yang tak sedikit, bangsa Indonesia menyatakan bebas dari penjajahan pada tanggal 17 Agustus 1945. Setelah 17 Agustus 1945 bangsa Indonesia terus berjuang untuk mempertahankan kemerdekaannya. Setelah merdeka bangsa Indonesia merasa kedudukannya sejajar dengan bangsabangsa lain di dunia. Oleh karena itu, bangsa Indonesia ingin menentukan nasib dan masa depannya sendiri. Fakta-fakta tersebut diatas tampak saling berhubungan untuk membentuk suatu konsep atau gagasan berupa "kemerdekaan". Dari contoh dan ilustrasi diatas dapat dikatakan bahwa fakta merupakan suatu kejadian atau peristiwa yang pernah terjadi atau pernah ada dan memberikan informasi yang bermakna bagi manusia, sehingga dapat membentuk sebuah konsep.

\section{Konsep}

Konsep merupakan abstraksi, yaitu suatu konstruksi logis yang terbentuk dari kesan, tanggapan, dan pengalaman-pengalaman kompleks. Konsep adalah ide abstrak yang dapat digunakan untuk mengadakan klasifikasi atau penggolongan yang pada umumnya dinyatakan dengan suatu istilah atau rangkain kata. Konsep dilahirkan berdasarkan atas kesepakatan bersama untuk penamaannya dari sejumlah fakta yang memiliki keterkaitan dan merupakan alat intelektual yang membantu kegiatan berpikir dan memecahkan masalah. Jadi dengan demikian, konsep adalah suatu pengertian yang disimpulkan dari sekumpulan fakta/ data yang memiliki ciri-ciri yang sama. Hal ini sejalan dengan pendapat banks bahwa konsep merupakan suatu kata atau frase abstrak yang bermanfaat untuk mengklasifikasikan atau menggolongkan sejumlah hal, gagasan, atau peristiwa. Berdasarkan pemaknaan tentang konsep, dapat dikemukakan suatu pengertian, bahwa konsep merupakan abstraksi dari suatu kejadian suatu hal-hal yang memiliki ciri-ciri yang sama atau ide tentang sesuatu didalam pikiran. Makin abstrak suatu konsep, makin besar kemampuan mengumpulkan fakta yang lebih spesifik, dan yang berada di bawahnya semakin tidak abstrak. Contoh "Bentuk Geografi” adalah sebuah konsep yang cukup luas. 
Konsep yang berada dibawahnya antara lain : sungai, danau, pegunungan, tebing, lautan, dan lain sebagainya.

\section{Generalisasi}

Generalisasi berasal dari kata "general" yang berarti umum atau menyeluruh. Oleh karena itu, generalisasi merupakan pengambilan kesimpulan secara umum dari suatu gejala informasi yang kita terima yang didukung oleh data dan fakta yang ada. Generalisasi merupakan sejumlah konsep yang memiliki karakteristik dan makna. Generalisasi adalah pernyataan tentang hubungan diantara konsep. Generalisasi mengungkapkan sejumlah besar informasi. ${ }^{4}$

Generalisasi ialah pernyataan tentang hubungan antara konsep-konsep dan berfungsi untuk membantu dalam memudahkan pemahaman suatu maksud pernyataan itu, berfungsi mengidentifikasi penyebab dan pengaruhnya, bahkan dapat digunakan untuk memprediksi suatu kejadian yang berhubungan dengan pernyataan yang ada dalam generalisasi tersebut. ${ }^{5}$

Generalisasi adalah pernyataan hubungan dua konsep atau lebih. Pernyataan tersebut boleh terbentang dari yang sangat sederhana ke yang sangat kompleks. Kadang-kadang mereka dikenal sebagai prinsip-prinsip atau hukum. Generalisasi menghubungkan konsep satu sama lain, selanjutnya merupakan kesimpulan dari pengalaman kita. Generalisasi bahkan lebih bermanfaat dibandingkan konsep, sebab generalisasi lebih mampu meringkas informasi dibandingkan dengan yang konsep lakukan. Generalisasi dapat juga menguraikan dunia sosial kita dengan teliti.generalisasi menyatakan hubungan antara dua konsep atau lebih, sering mengidentifikasi penyebab dan efek, dapat digunakan untuk meramalkan suatu kejadian dimasa depan yang berhubungan dengan yang dinyatakan dalam generalisasi. Berpijak pada pernyataan tersebut dapat dikemukakan bahwa generalisasi merupakan pernyataan tentang hubungan antara

\footnotetext{
${ }^{4}$ Fakih Samlawi dan Bunyamin Maftuh, Konsep Dasar IPS (Jakarta : DIRJENDIKTI, 1998), hlm. 9.

${ }^{5}$ Ibid, hlm. 153.
} 
konsep-konsep yang berfungsi untuk membantu dalam memudahkan pemahaman suatu maksud pernyataan bersangkutan, mengidentifikasi penyebab dan pengaruhnya, bahkan dapat digunakan untuk memprediksi suatu kejadian yang berhubungan dengan pernyataan yang ada dalam generalisasi bersangkutan.

\section{Teori}

Teori yaitu prinsip umum yang menjelaskan hakikat gejala atau hubungan gejala berupa rumus, aturan, kaidah dan sebagainya. Teori merupakan rangkaian fakta-fakta, konsep-konsep, dan generalisasi-generalisasi, serta perkiraan tentang implikasi (akibat) dari rangkaian fakta-fakta, konsep-konsep, dan generalisasi-generalisasi tersebut yang satu sama lainnya sangat berhubungan. Menurut Goetz dan Le Compte, Teori dapat di bagi menjadi :

a. Grand Theory : sistem yang secara ketat mengkaitkan preposisipreposisi dan konsep-konsep yang abstrak sehingga dapat digunakan, menguraikan, menjelaskan, dan memprediksi secara komprehensif sejumlah fenomena besar secara non-probabilitas.

b. Theorical models : keterhubungan yang longgar (tidak ketat) antara sejumlah asumsi, konsep, dan preposisi yang membentuk pandangan ilmuwan tentang dunia.

c. Formal dan Middle-range theory : teori formal dan tingkat menengah yaitu sebagai preposisi yang berhubungan dikembangkan untuk menjelaskan beberapa kelompok tingkah laku manusia yang abstrak. ${ }^{6}$ Maksudnya yaitu seperti sebuah konsep yang pemahamannya abstrak.

${ }^{6}$ Ibid, hlm. 156-158. 


\section{BAB III \\ PENUTUP}

\section{A. Kesimpulan}

Struktur suatu disiplin ilmu adalah bentuk konsepsi yang membatasi pokok masalah yang diselidiki dari suatu disiplin dan pengawasan / pengendalian terhadap penelitiannya. Struktur disiplin ilmu meliputi dua bagian, yaitu, substantive conceptual structure dan syntactical structure. Substantive conceptual structure merupakan konsep-konsep yang menjadi kerangka berpikir atau frame of reference dalam meneliti sesuatu.Substantive conceptual structure akan berhubungan dan mengarahkan penelitian melalui serangkaian pertanyaan. Syntactical structure berhubungan dengan iquiry atau penelitian yang dilakukan oleh disiplin bersangkutan. Syntactical structure menyangkut masalah-masalah arah yang akan ditempuh dalam penelitian, cara pengumpulan data, cara menguji data, kriteria yang dipakai dalam menetapkan kulitas data, ukuran untuk menentukan relevansi dan penting tidak pentingnya data yang diperoleh, serta jalan yang ditempuh disiplin ilmu tersebut dari data mentah melalui interpretasi menuju pada kesimpulan. Berdasarkan substantive conceptual structure dan syntactical structure dengan jelas akan tampak batang tubuh suatu disiplin ilmu (the body of knowledge) yang strukturnya mencakup fakta, konsep, generalisasi, dan teori.

\section{B. Saran}

Mengingat keterbatasan pengetahuan dan keterampilan yang dimiliki oleh kami, maka untuk mendapatkan pemahaman yang lebih mendasar lagi, disarankan kepada pembaca untuk membaca literatur-literatur yang telah dilampirkan pada daftar pustaka. 


\section{DAFTAR PUSTAKA}

Arifin, Noor, Ilmu sosial Dasar (Bandung: Pustaka setia, 2007)

Djamarah, Syaiful Bahri, Konsep dan defenisi konseptual (Jakarta: PT. Raja Grafindo Persada, 2008)

Karima, Muhammad Kaulan, Ilmu pengetahuan sosial (Medan: Perdana publishing, 2019)

Samlawi, Fakih dan Bunyamin Maftuh, Konsep Dasar Ips (Jakarta: DIRJENDIKTI, 1998)

Suhada, Idad, Konsep Dasar Ips( Bandung: CV Insan Mandiri, 2012). 